\title{
A LUTA PELA TERRA E A POLÍTICA DE ASSENTAMENTOS RURAIS NO BRASIL: A REFORMA AGRÁRIA CONSERVADORA
}

\section{LA LUCHA POR LA TIERRA Y LA POLÍTICA DE ASENTAMIENTOS RURALES EM BRASIL: LA REFORMA AGRARIA CONSERVADORA}

\section{THE STRUGGLE FOR LAND AND THE POLICY OF RURAL SETTLEMENTS IN BRASIL}

\author{
Eduardo Paulon Girardi \\ UFMT - Campus de Cuiabá \\ Nera - Núcleo de Estudos, Pesquisas e Projetos de Reforma Agrária (Unesp) \\ epgirardi@yahoo.com.br \\ Bernardo Mançano Fernandes \\ Unesp - Campus de Presidente Prudente \\ Nera - Núcleo de Estudos, Pesquisas e Projetos de Reforma Agrária (Unesp) \\ bmf@,fct.unesp.br
}

\section{Resumo}

Este artigo analisa a luta pela terra e a sua conquista no Brasil. A ocupação de terra é principal forma de luta dos camponeses organizados em movimentos socioterritoriais no Brasil e o Estado, em resposta a essas ações, cria os assentamentos rurais. Consideramos inicialmente as contradições do campo brasileiro e, a partir de algumas premissas, analisamos a política de assentamentos rurais como uma estratégia para não realizar uma reforma agrária ampla no país. A política de assentamentos rurais caracteriza, por seu alcance reduzido, a reforma agrária conservadora executada no Brasil. Essa política não consegue desconcentrar a terra, diminuir as desigualdades sociais ou impedir o êxodo rural, além de ter a Amazônia como válvula de escape para não reformar as regiões de ocupação consolidada no centro-sul e no Nordeste. As análises deste artigo fazem parte do Atlas da Questão Agrária Brasileira ${ }^{1}$ (www.fct.unesp.br/nera/atlas).

Palavras-chave: ocupações de terra; assentamentos rurais; reforma agrária conservadora; Amazônia.

\section{Resumen}

Este artículo analiza la lucha por la tierra y su conquista en Brasil. La ocupación de tierra es la principal forma de lucha de campesinos organizados en movimientos socioterritoriales en Brasil y el Estado, en respuesta a esas acciones, crea los

\footnotetext{
${ }^{1}$ Este artigo foi elaborado a partir de extratos da tese: "GIRARDI, Eduardo Paulon. Proposição teóricometodológica de uma Cartografia Geográfica Crítica e sua aplicação no desenvolvimento do Atlas da Questão Agrária Brasileira. 2008. Tese (Doutorado em Geografia) - Faculdade de Ciências e Tecnologia, Universidade Estadual Paulista, Presidente Prudente, 2008. Disponível em: $<$ www.fct.unesp.br/nera/atlas $>$." A tese foi desenvolvida no programa de Pós-Graduação em Geografia da Unesp de Presidente Prudente, orientada pelo Prof. Dr. Bernardo Mançano Fernandes e com o apoio da FAPESP.
} 
asentamientos rurales. Consideramos inicialmente las contradicciones del campo brasilero y, a partir de algunas premisas, analizamos la política de asentamientos rurales como una estrategia para no realizar una reforma agraria amplia em el país. Por su alcance reducido, demostramos que la política de asentamientos rurales caracteriza la reforma agraria conservadora ejecutada em Brasil, ya que no consigue desconcentrar la tierra, disminuir las desigualdades sociales o impedir el éxodo rural, además de tener la Amazonia como válvula de escape para no reformar las regiones de ocupación consolidada en el centro sur y en el nordeste. Los análisis de este artículo hacen parte del Atlas de la Cuestión Agraria Brasilera.

Palabras clave: ocupaciones de tierra; asentamientos rurales; reforma agrária conservadora; Amazonia.

\begin{abstract}
This article analyzes the struggle for the land and its conquest in Brazil. Land occupation is the main way of struggle employed by peasants on socioterritorial movements in Brazil and the State, as reply to such actions of struggle, creates rural settlements. From some contradictions formerly exposed, the policy of rural settlements of the Brazilian government is analyzed as a strategy for not performing a comprehensive agrarian reform in the country. Due to its restrictions, the policy of rural settlements constitute the conservative agrarian reform performed in Brazil since this policy cannot deconcentrate the land, reduce social inequality or avoid the rural exodus, moreover it has Amazon as a conservative alternative for not reforming consolidated occupation regions in the Center-South and in North-East.
\end{abstract}

Keywords: land occupation; rural settlements; conservative agrarian reform; Amazon.

\title{
INDTRODUÇÃO
}

O Brasil é um país caracterizado por desigualdades sociais e regionais resultantes da concentração da riqueza. Os problemas da questão agrária, relativos à vida e produção no campo, compõem o conjunto de questões estruturais que barram outro modelo de desenvolvimento ${ }^{2}$ para o país, mantendo suas características contraditórias em favor de um pequeno número privilegiados que detém os meios de

\footnotetext{
${ }^{2} \mathrm{O}$ trabalho de Gómez (2006) considera que o modelo de desenvolvimento neoliberal é imposto através de órgãos internacionais (principalmente o Banco Mundial e o Fundo Monetário Internacional) e dos países capitalistas desenvolvidos, que controlam esses órgãos. $\mathrm{O}$ autor defende que o desenvolvimento imposto pelas instituições neoliberais é baseado em um discurso que opera como controle social. Este discurso tem como principal função a afirmação - e repetição até a sua aceitação - de que as políticas neoliberais para o desenvolvimento funcionam, o que não ocorre. A afirmação da eficiência dessas políticas é o principal instrumento para a aceitação deste modelo de desenvolvimento. O desenvolvimento imposto pelo Banco Mundial tem como função tentar solucionar os problemas causados pelo capitalismo por meio das próprias regras capitalistas, o que é impossível. Este desenvolvimento é utilizado pelo capitalismo como estratégia para a sua própria reprodução. Gómes denomina este desenvolvimento de desenvolvimento possível, pois é o único praticável dentro das regras do capitalismo. Contudo, haveria uma outra via, que o autor denomina de desenvolvimento intolerável aos olhos do capitalismo, já que este modelo contraria suas regras.
} 
produção e controla a política e as finanças. Com apenas $18,8 \%$ da população vivendo no campo, um êxodo rural de 4,2 milhões de pessoas no período 1991-2000 e a extinção de 1,5 milhões de postos de trabalho ${ }^{3}$ no campo no período 1996-2006 (IBGE, 2006), o Brasil é o quinto maior exportador mundial de produtos agropecuários, especialmente soja, açúcar e álcool, suco de laranja, café, papel e celulose, fumo, algodão e milho, além de ser o maior exportador mundial de carne. Esses produtos são responsáveis por grande parte do superávit da balança comercial brasileira, que garante aos ricos e à classe média a inserção no circuito global de consumo.

A contradição aparece quando verificamos que em 2004 o Instituto Brasileiro de Geografia e Estatística (IBGE) contou 72 milhões de brasileiros residindo em domicílios com algum tipo de insegurança alimentar, ou seja, não tinham garantias de alimento em quantidade e em qualidade. Desses brasileiros, 15,4 milhões eram

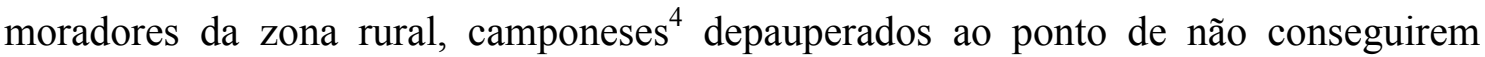
estrutura mínima para produzir nas suas terras o seu próprio alimento. A Organização das Nações Unidas para a Agricultura (FAO) (2008) calculou que em 2005 seis por cento da população brasileira, cerca de 11 milhões de pessoas, sofriam de desnutrição. Por fim, estima-se que 12,9 milhões de famílias têm renda inferior a $\mathrm{R} \$ 137,00$ por membro (IBGE, 2007) e, por isso, 11,6 milhões delas recebiam em 2009 auxílio do Programa Bolsa Família ${ }^{5}$, que pode variar de $\mathrm{R} \$ 20,00$ a R\$ 182,00 por família.

Esses dados indicam que o Brasil é um país sem segurança alimentar, já que grande parte da população não tem acesso aos alimentos. Por conseguinte, o país também não goza de soberania alimentar, já que o cerceamento à terra e o não acesso aos meios adequados para nela produzir não permitem que todos os que almejem possam plantar. Ainda contra a soberania alimentar contribui o mando internacional do sistema do agronegócio, que estabelece as regras de como e o que produzir para exportar. Além desses aspectos, a distribuição da terra no Brasil ainda conserva a estrutura concentrada cujas raízes históricas remontam do colonialismo ibérico sobre a América Latina. Em 2003, segundo dados do Instituto Nacional de Colonização e Reforma Agrária (INCRA), o índice de Gini da estrutura fundiária brasileira era de

\footnotetext{
${ }^{3}$ A mesma definição de "Pessoal Ocupado" do Censo Agropecuário 2006 do IBGE. Compreende todas as pessoas que trabalham nos estabelecimentos agropecuários exercendo atividades ligadas à agropecuária ou que lhe dêem suporte. Compreende familiares e não familiares; com relações formais (assalariamento com registro) ou informais (trabalho familiar, assalariamento sem registro, parceria etc.).

${ }^{4}$ Sobre o conceito de camponês ver Girardi (2008, pp.90-122).

${ }^{5}$ Ver www.mds.gov.br.
} 
0,816, o que demonstra a alta concentração da terra no país, já que quanto mais próximo de um maior é a concentração.

Não bastasse, nas últimas décadas tem ocorrido a incorporação constante de novas terras na estrutura fundiária brasileira. Entre 1992 e 2003 foram acrescidos 108,5 milhões de hectares na estrutura fundiária, principalmente na Amazônia e nos cerrados. Entre 1998 e 2007 o Instituto Nacional de Pesquisas Espaciais (INPE) registrou desflorestamento de 19,1 milhões de hectares da Amazônia.

Esta incorporação de novas terras ocorre com a manutenção da concentração, já que o índice de Gini em 1992 era de 0,826 e apresentou decréscimo de apenas 0,010 para o ano de 2003. Além disso, essas terras são incorporadas com fins especulativos, pois em 1998 as terras exploráveis não exploradas no Brasil somavam 75,4 milhões de hectares. Este processo se agravará com a Medida Provisória 458, aprovada pelo parlamento e pelo Presidente Luiz Inácio Lula da Silva em 2009, e que possibilita a legalização de "posses"6 de até 1.500 hectares num total de 67 milhões de hectares na Amazônia. Este é mais um passo na investida sobre novas áreas em detrimento da promoção da reforma agrária sobre áreas já abertas.

Sobre as constatações acima delineadas alicerçamos nossa afirmativa de que a reforma agrária é socialmente justificável e indispensável para proporcionar o desenvolvimento do Brasil. É Também dessas constatações que retiramos a premissa para a análise que desenvolveremos doravante: a política de assentamentos rurais constitui uma reforma agrária conservadora.

\section{O SIGNIFICADO E A VALIDADE DA LUTA PELA TERRA}

A luta pela terra através das ocupações e a conseqüente criação de assentamentos rurais é uma forma de recriação do campesinato, o que pode ocorre também através de arrendamento, meação, parceria ou compra da terra. As ocupações constituem um momento da luta pela terra. Como resposta às ações dos movimentos socioterritoriais, os governos criam assentamentos rurais que, em princípio, constituem

\footnotetext{
6 "Posses" (com aspas) porque consideramos que a legalização de áreas além de 200 ha é, na verdade, a regularização de grilos. Mesmo que hoje a legislação só permita o desflorestamento de $20 \%$ das propriedades rurais no bioma amazônico, sabendo da incapacidade de fiscalização na região, dificilmente a floresta não sofrerá investidas sobre área superiores aos $20 \%$. Também não há garantia de que no futuro a legislação que restringe o desflorestamento nas propriedades da Amazônia em 20\% não seja alterada, visto a força política do setor latifundiário.
} 
a conquista da terra. Os assentamentos significam uma nova etapa da luta: o processo pela conquista da terra. Ainda é necessário conquistar condições de vida e produção na terra; resistir na terra e lutar por um outro tipo de desenvolvimento que permita o estabelecimento estável da agricultura camponesa.

No Brasil, a ocupação é a principal estratégia de luta pela terra realizada pelos movimentos socioterritoriais camponeses. Os dados do Banco de Dados da Luta Pela Terra (DATALUTA) ${ }^{7}$ em 2006 mostram que no país, entre 2000 e 2006, foram registradas ocupações de terra realizadas por 86 diferentes movimentos socioterritoriais. As áreas ocupadas são principalmente latifúndios, terras devolutas e imóveis rurais onde leis ambientais e trabalhistas foram desrespeitadas. De modo geral, as propriedades ocupadas são aquelas que apresentam indicativos de descumprimento da função social da terra, definida no artigo 186 da Constituição Federal ${ }^{8}$. Como o Estado não apresenta iniciativa para cumprir a determinação constitucional, os movimentos socioterritoriais agem para que isso aconteça. Ultimamente, além de lutar contra o latifúndio, os movimentos socioterritoriais camponeses iniciaram a luta contra a territorialização do agronegócio em suas formas mais intensas e, por isso, as ocupações têm ocorrido em áreas de produção de soja transgênica, cana-de-açúcar e plantações de eucalipto, por exemplo.

Em princípio, a ocupação de áreas economicamente produtivas seria muito mais uma forma de protesto, visto que pela constituição (art. 185) elas não são suscetíveis à desapropriação para a reforma agrária. O artigo 186 estabelece que a propriedade deve cumprir sua função social, que compreende as dimensões ambiental, trabalhista e de bem estar do proprietário e dos trabalhadores. Na interpretação desses dois artigos, Pinto Jr. e Farias (2005) afirmam que não basta que a propriedade rural seja produtiva (art. 185) no sentido economicista para que não seja passível de desapropriação; ela deve ser produtiva respeitando simultaneamente os princípios do art. 186. A produtividade não pode ser alcançada sob conseqüência de desrespeito aos

\footnotetext{
${ }^{7}$ O DATALUTA é um banco de dados desenvolvido no Núcleo de Estudos, Pesquisas e Projetos de Reforma Agrária (NERA) da Unesp de Presidente Prudente. O cerne deste banco de dados consiste em coletar informações sobre ocupações de terras e assentamentos rurais de diversas fontes e, através de um processo de comparação e agregação, agrupá-las em um mesmo conjunto de dados para os municípios brasileiros, tornando assim os dados mais completos. A metodologia e os dados do DATALUTA podem ser encontrados em www.fct.unesp.br/nera .

8 Art. 186 da Constituição Federal. A função social é cumprida quando a propriedade rural atende, simultaneamente, segundo critérios e graus de exigência estabelecidos em lei, aos seguintes requisitos: I) aproveitamento racional e adequado; II) utilização adequada dos recursos naturais disponíveis e preservação do meio ambiente; III) observância das disposições que regulam as relações de trabalho; IV) exploração que favoreça o bem-estar dos proprietários e dos trabalhadores.
} 
aspectos da função social, de forma que essas duas características são indissociáveis e "a função social é continente e conteúdo da produtividade" (p.48). Assim, caso a produção seja conseguida a partir do descumprimento das dimensões estabelecidas pelo artigo 186, o aspecto produtivo não isenta a propriedade de desapropriação para a reforma agrária. É por isso que o agronegócio, através de suas práticas, desrespeita a função social da terra. Por isso, as ocupações de propriedades cultivadas que não cumprem a função social são legítimas no sentido da luta, já que podem ser suscetíveis à desapropriação segundo a interpretação da lei apresentada acima.

A reforma agrária é necessidade historicamente defendida para a resolução dos problemas agrários no Brasil. Em nossa análise da luta pela terra tomamos o período de 1988 até 2006, quando ela foi intensificada. Nos sucessivos governos deste período, as ações de reforma agrária no Brasil têm sido baseadas principalmente nas políticas de criação de assentamentos rurais e de concessão de crédito aos camponeses. Partimos do princípio de que uma reforma agrária completa no Brasil deve, simultaneamente, reformar a estrutura fundiária do país, possibilitar o acesso dos camponeses à terra e fornecer-lhes condições básicas de vida e produção. Neste sentido, o II PNRA (Plano Nacional de Reforma Agrária) avançou ao apresentar uma compreensão ampliada de reforma agrária. Porém, como demonstraremos, a execução do plano tem apresentado uma reforma conservadora da estrutura fundiária através da criação de assentamentos rurais. Consideramos que no período analisado houve uma reforma agrária conservadora, pois a forma como é conduzida a política de assentamentos conserva a estrutura das regiões de ocupação consolidada, isto é, centrosul e Nordeste, de forma que o cumprimento dos princípios constitucionais é muito restrito. A partir desta premissa, nosso objetivo é compreender o quanto reformadora é a política de assentamentos rurais que fundamenta esta reforma agrária conservadora.

\section{OCUPAÇÕES DE TERRA, ASSENTAMENTOS RURAIS E GOVERNOS}

A partir de 1995, primeiro mandado de Fernando Henrique Cardoso (1995-1998), houve um aumento significativo de famílias em ocupações e de famílias $\operatorname{assentadas}^{9}$ ( gráfico 1). As ocupações atingiram o seu máximo em 1999 (897 ocupações

\footnotetext{
${ }^{9}$ Para os dados de famílias em ocupações e famílias assentadas calcula-se a média de cinco pessoas por família. Os dados de famílias assentadas são referentes ao número famílias que o assentamento comporta
} 
e 118.620 famílias em ocupações), ano em que Fernando Henrique Cardoso assumiu seu segundo mandato (1999-2002). O aumento constante do número de ocupações fez com que o Presidente publicasse então a Medida Provisória 2.027-38 de 4 de maio de 2000, que criminalizava a luta pela terra. A criminalização ficou mais evidente na Medida Provisória 2.109-52 de 24 de maio de 2001, que substituiu a anterior ${ }^{10}$. O texto dessas Medidas Provisórias prevê o impedimento, por dois anos, da vistoria de imóveis rurais onde tenham sido realizadas ocupações de terra e também exclui os trabalhadores que participam de ocupações de terra dos programas de reforma agrária. Com essas medidas coercitivas às ações dos movimentos sociais camponeses, o número de famílias em ocupações diminuiu drasticamente e o número de famílias assentadas acompanhou esta queda. Isso quer dizer que o governo atingiu seu objetivo: diminuir a quantidade de novas famílias assentadas. A análise conjunta deste fato e da evolução das ocupações e assentamentos (gráfico 1) mostra que as famílias só são assentadas devido à pressão realizada pelas ocupações de terra.

Em 2003, com a eleição do Presidente Luiz Inácio Lula da Silva, houve crescimento das ocupações e, conseqüentemente, dos assentamentos. Isso possivelmente ocorreu pela minimização da aplicação da criminalização da luta pela terra, prevista na Medida Provisória, e pela esperança que os movimentos socioterritoriais depositavam no Presidente Lula para a realização de uma reforma agrária mais ampla, o que não ocorreu. Os dados de famílias assentadas mostram que nem mesmo no aspecto quantitativo há diferença entre os governos de FHC e de Lula, pois, durante os oito anos de governo de Fernando Henrique Cardoso, foram assentadas 457.668 famílias e, no primeiro mandato de Lula, foram assentadas 252.019. O total de famílias assentadas no primeiro mandato de Lula contempla apenas 63\% das 400 mil famílias previstas no II Plano Nacional de Reforma Agrária (PNRA) para o período. A tabela 1 mostra os dados anuais da luta pela terra e da política de assentamentos rurais e os mapas da prancha 1 permitem comparar o número de famílias em ocupações de terra

em sua capacidade máxima. Esses dados não dizem respeito, por exemplo, aos casos em que as famílias desistem de seus lotes e outras famílias são assentadas. Este processo não é acompanhado. A quantidade de famílias nos assentamentos pode ser inferior, em projetos de assentamentos não totalmente ocupados, o que pode ocorrer no início da implantação, ou superior, no caso de outras famílias que passam a viver nos lotes com as famílias legalmente beneficiárias. No caso das famílias em ocupações de terra, a mesma família pode participar de diversas ocupações na sua trajetória de luta, que pode durar anos até que consiga um lote.

${ }^{10}$ Atualmente essas Medidas Provisórias estão em tramitação sob a forma da MP 2.183-56 de 24 de agosto de 2001 . 
e de famílias assentadas nas microrregiões brasileiras ${ }^{11}$ nos três últimos períodos de governo. Apesar dos totais da tabela 1 indicarem um equilíbrio entre famílias em ocupações e famílias assentadas, como demonstramos a partir do tópico 3, este fato não indica a realização plena da reforma agrária ou que todos que demandaram terra foram contemplados. A análise desta questão é o centro deste artigo.

TABELA 1 - Brasil - A luta pela terra e sua conquista - 1979-2006

\begin{tabular}{|c|r|r|r|r|r|}
\hline & $\begin{array}{c}\text { Ocupações } \\
\text { de terra }\end{array}$ & $\begin{array}{c}\text { Famílias em } \\
\text { ocupações }\end{array}$ & $\begin{array}{c}\text { Assenamentos } \\
\text { criados }\end{array}$ & $\begin{array}{c}\text { Famílias } \\
\text { assentadas }\end{array}$ & $\begin{array}{c}\text { Área dos } \\
\text { assentamentos } \\
\text { (ha) }\end{array}$ \\
\hline $1979-1987$ & - & - & 436 & 105.778 & \multicolumn{1}{c|}{7.247 .245} \\
\hline 1988 & 71 & 10.491 & 123 & 28.251 & 2.053 .290 \\
\hline 1989 & 86 & 20.350 & 115 & 12.136 & 696.200 \\
\hline 1990 & 50 & 7.314 & 31 & 3.620 & 158.755 \\
\hline 1991 & 85 & 14.990 & 87 & 15.464 & 774.640 \\
\hline 1992 & 93 & 17.838 & 167 & 22.251 & 1.262 .894 \\
\hline 1993 & 116 & 19.442 & 74 & 5.513 & 196.473 \\
\hline 1994 & 163 & 23.016 & 42 & 10.346 & 503.141 \\
\hline 1995 & 186 & 42.746 & 409 & 63.622 & 2.957 .220 \\
\hline 1996 & 458 & 78.263 & 505 & 64.964 & 3.912 .346 \\
\hline 1997 & 513 & 69.453 & 710 & 92.296 & 3.645 .960 \\
\hline 1998 & 828 & 111.396 & 757 & 79.481 & 3.039 .558 \\
\hline 1999 & 897 & 118.620 & 599 & 51.379 & 2.215 .473 \\
\hline 2000 & 528 & 83.790 & 426 & 38.463 & 2.182 .712 \\
\hline 2001 & 283 & 45.537 & 475 & 35.606 & 1.833 .080 \\
\hline 2002 & 273 & 40.966 & 417 & 31.857 & 2.584 .210 \\
\hline 2003 & 555 & 92.883 & 327 & 29.553 & 5.290 .618 \\
\hline 2004 & 702 & 118.225 & 498 & 44.548 & 5.371 .812 \\
\hline 2005 & 569 & 73.283 & 1.056 & 124.040 & 14.523 .107 \\
\hline 2006 & 553 & 58.717 & 412 & 53.878 & 4.104 .033 \\
\hline TOTAL & 7.009 & 1.047 .320 & 7.666 & 913.046 & 64.552 .767 \\
\hline Dados: DATALUTA & & & & & \\
\hline Org.: Eduardo Paulon Girardi & & & & \\
\hline
\end{tabular}

GRÁFICO 1 - Brasil - A luta pela terra e sua conquista - 1979-2006

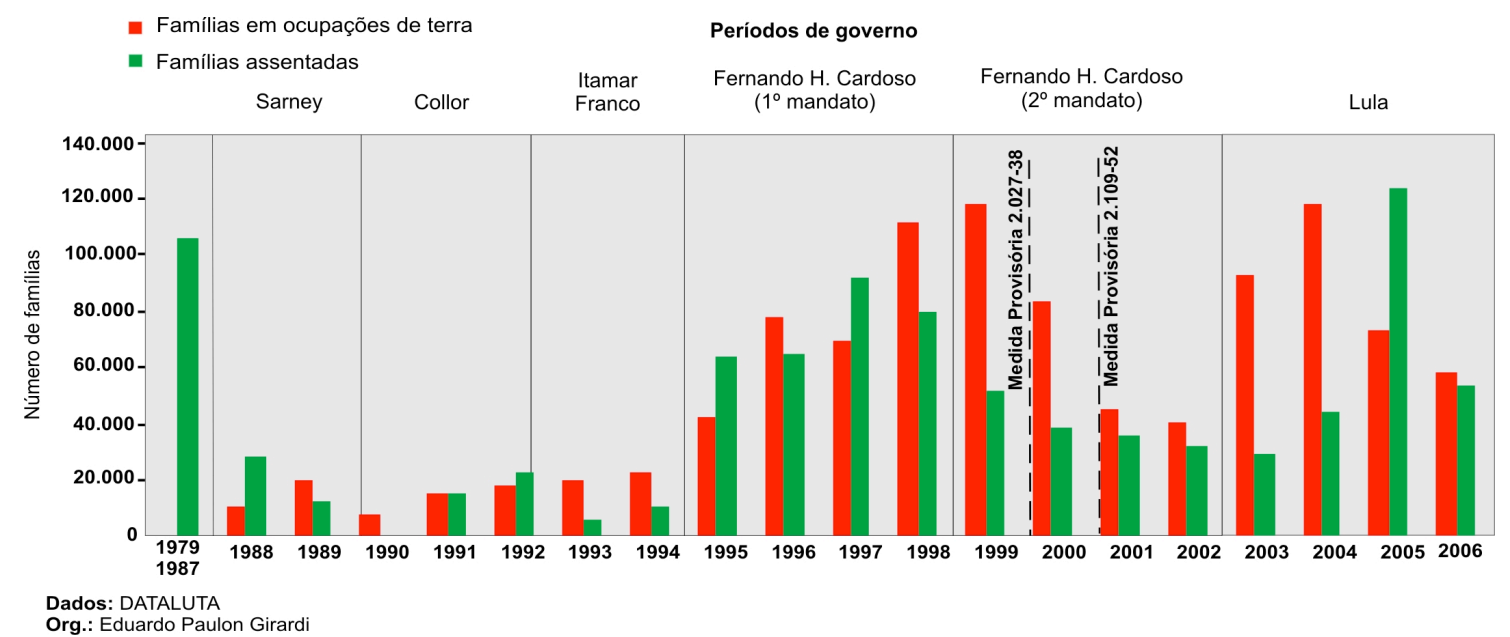

${ }^{11}$ Microrregiões segundo a delimitação do IBGE. 


\section{PRANCHA 1}

OCUPAÇÕES, ASSENTAMENTOS E PERÍODOS DE GOVERNO - 1995-2006
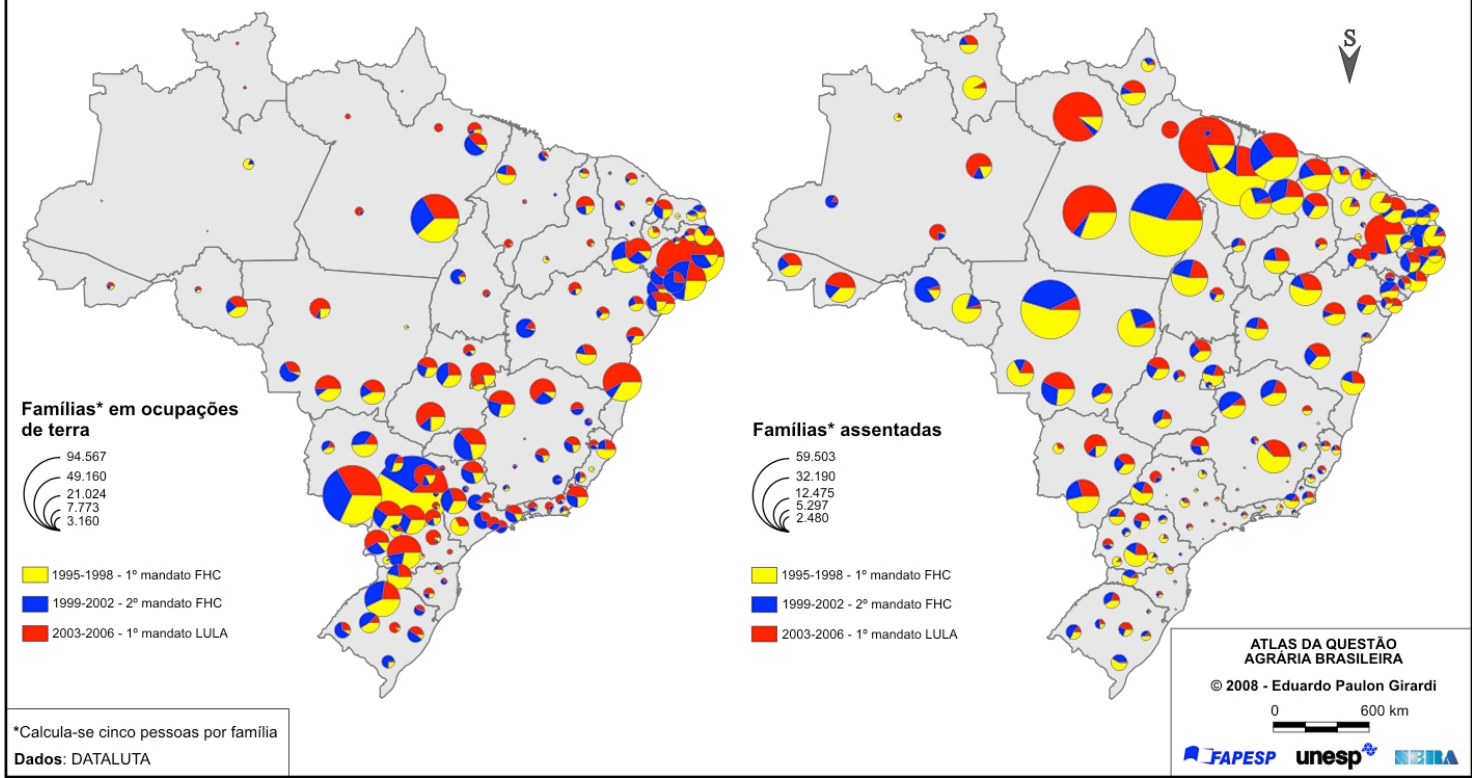

Os mapas da prancha 2 apresentam os dados da luta pela terra e os da prancha 3 representam os dados da conquista da terra. As ocupações e as famílias que delas participam concentram-se no centro-sul e na porção oriental do Nordeste. As famílias assentadas concentram-se na porção norte do País. As informações mais importantes desses mapas são o número de famílias em ocupações, que indica a gravidade dos problemas agrários, e a quantidade de famílias assentadas, que indica resposta do Estado para a solução do problema.

PRANCHA 2

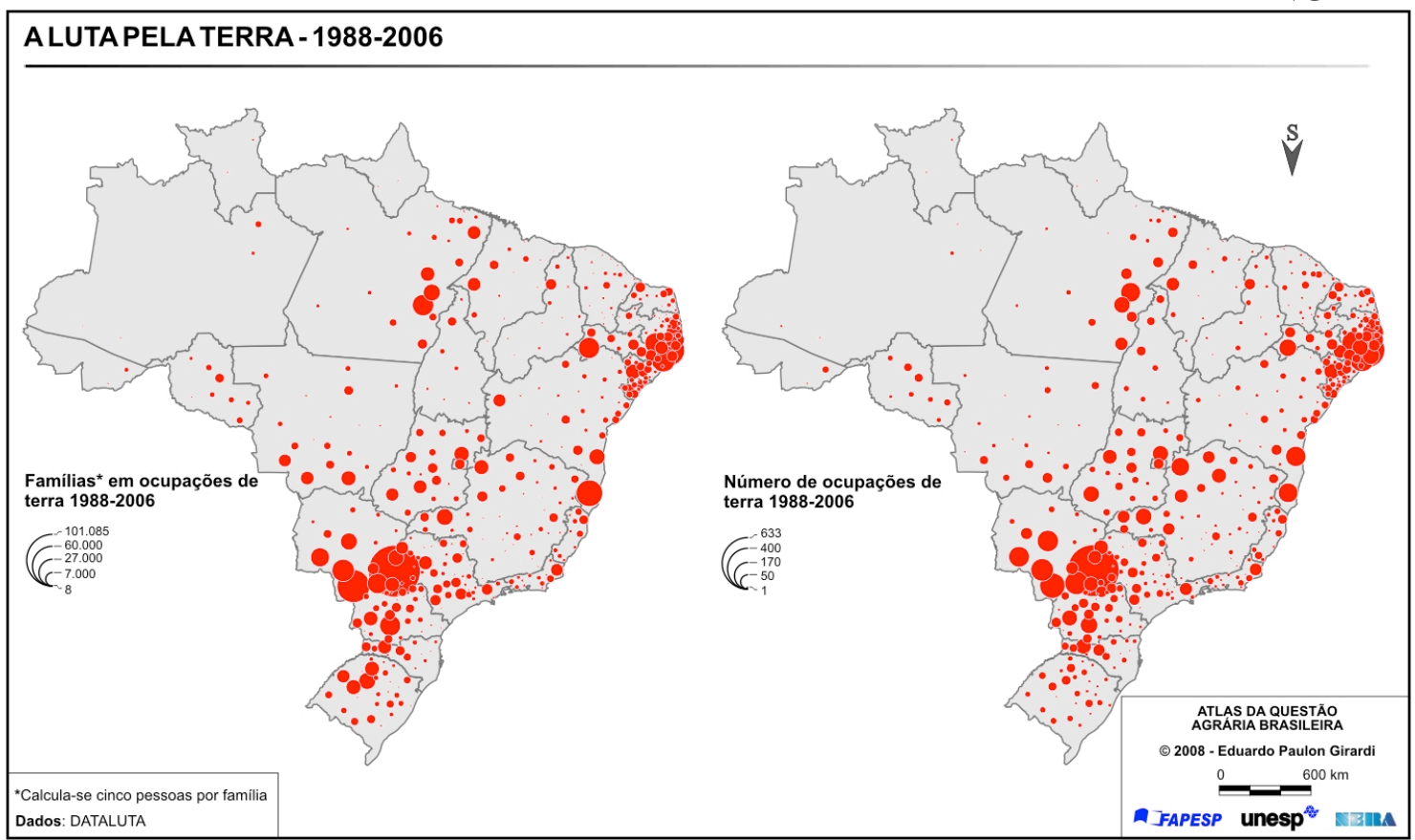


PRANCHA 3

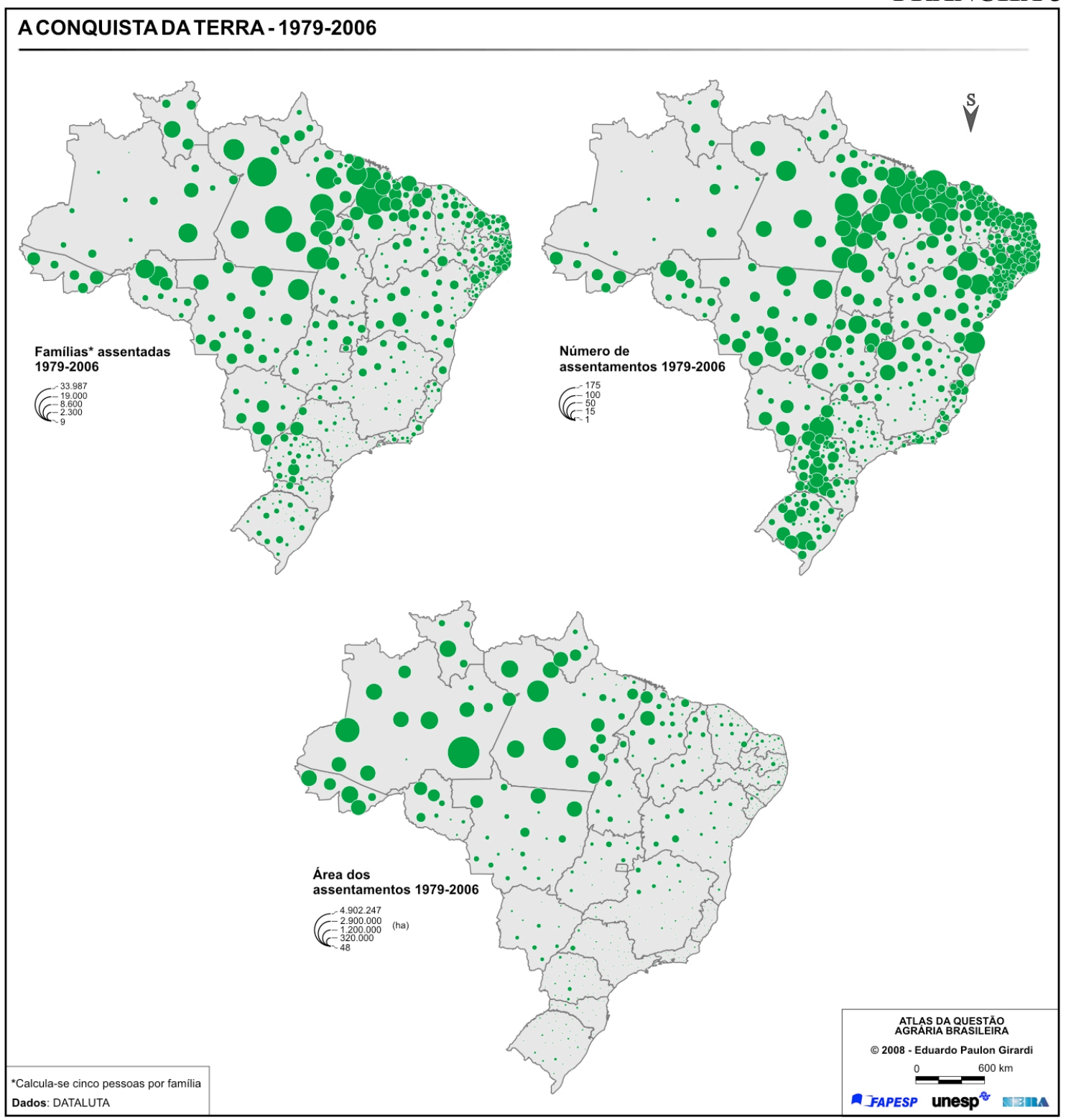

\section{O CONSERVADORISMO DA POLÍTICA DE ASSENTAMENTOS RURAIS}

Desde 1988 foram realizadas no país mais de sete mil ocupações de terra, das quais participaram cerca de um milhão ${ }^{12}$ de famílias cujos lares foram (ou ainda são), por vários anos, os barracos de lona dos acampamentos. Em resposta, os governos criaram desde então 7.230 assentamentos rurais, cuja área total de 57,3 milhões de hectares comporta cerca de 900 mil famílias. Poderíamos então concluir que restariam apenas cerca de 100 mil famílias para serem assentadas e a reforma agrária estaria concluída? A resposta positiva à qual conduz a "matemática" da reforma agrária conservadora é facilmente derrubada pela análise geográfica.

\footnotetext{
${ }^{12}$ Este número é provavelmente superior, visto que não há informações sobre o número de famílias para 867 ocupações de terra.
} 
O aspecto geográfico (aqui como referência ao localizacional) da política de assentamentos não constitui uma resposta local às demandas/denúncias dos movimentos socioterritoriais. A geografia da política de assentamentos rurais é um dos elementos que denunciam seu caráter conservador, para o que contribui também a tipologia dos "assentamentos rurais".

A primeira evidência do conservadorismo da política de assentamentos rurais aparece quando agrupamos os números da luta pela terra e de sua conquista por macrorregião. Entre 1988 e 2006, de todas as famílias que participaram de ocupações de terra no Brasil, apenas cinco por cento o fizeram na região Norte, porém, entre as famílias "assentadas" pelos governos no mesmo período, $40 \%$ receberam lotes na região Norte. CentroOeste e Nordeste apresentam equilíbrio entre a proporção numérica (mas não necessariamente localizacional!) de famílias em ocupações e famílias assentadas em relação ao total brasileiro. Já no caso do Sul e, especialmente do Sudeste, ao contrário do que ocorre no Norte, a participação nas ocupações é bem superior ao assentamento de famílias. Por fim, se tomarmos a área dos assentamentos rurais, há uma diminuição do total no sentido norte-sul.

TABELA 2 - Brasil - Macrorregiões - A luta pela terra e sua conquista - 1988-2006

\begin{tabular}{|c|c|c|c|c|c|c|c|c|c|c|}
\hline \multirow[t]{2}{*}{ Região } & \multicolumn{2}{|c|}{ Ocupações de terra } & \multicolumn{2}{|c|}{$\begin{array}{l}\text { Famílias em } \\
\text { ocupações }\end{array}$} & \multicolumn{2}{|c|}{$\begin{array}{l}\text { Assentamentos } \\
\text { criados }\end{array}$} & \multicolumn{2}{|c|}{$\begin{array}{c}\text { Famílias } \\
\text { assentadas }\end{array}$} & \multicolumn{2}{|c|}{$\begin{array}{c}\text { Área dos } \\
\text { assentamentos }\end{array}$} \\
\hline & absoluto & $\%$ & absoluto & $\%$ & absoluto & $\%$ & absoluto & $\%$ & ha & $\%$ \\
\hline Norte & 571 & 8,2 & 84.853 & 8 & 1.493 & 21 & 320.019 & 40 & 40.061 .207 & 70 \\
\hline Nordeste & 2.454 & 35,0 & 339.590 & 32 & 3.309 & 46 & 279.418 & 35 & 8.799 .654 & 15 \\
\hline Sudeste & 1.816 & 25,9 & 263.416 & 25 & 652 & 9 & 42.995 & 5 & 1.263 .323 & 2 \\
\hline Sul & 1.025 & 14,6 & 166.473 & 16 & 757 & 10 & 37.738 & 5 & 826.687 & 1 \\
\hline Centro-Oeste & 1.138 & 16,2 & 192.868 & 18 & 1.014 & 14 & 126.786 & 16 & 6.347 .770 & 11 \\
\hline BRASIL & 7.004 & 100,0 & 1.047 .200 & 100 & 7.225 & 100 & 806.956 & 100 & 57.298 .641 & 100 \\
\hline
\end{tabular}

O mapa 1 representa de forma detalhada as famílias em ocupações e as famílias assentadas de 1988 até 2006. A oposição norte-sul evidencia a ineficácia regional da política de assentamentos rurais, indicando que os problemas agrários locais não são resolvidos, o que mantém o conflito e anula o desenvolvimento. $\mathrm{O}$ aspecto mais elementar da concentração das ocupações no centro-sul e no Nordeste é que essas são as regiões em que se concentra a população brasileira ${ }^{13}$. Aí também se concentram os milhões de expropriados e camponeses em vias de desintegração devido à modernização da agricultura e industrialização do país, não planejadas de forma adequada para garantir a distribuição da riqueza e absorção desta população por outros setores. Além da concentração populacional, as regiões de ocupação consolidada, onde se concentram as ocupações de terra, são caracterizadas pela melhor infraestrutura para produção, maior mercado consumidor e acesso a serviços básicos como educação,

13 Segundo a Contagem da População 2007 do IBGE, as cinco macrorregiões concentram as seguintes proporções da população total brasileira: Norte 7,9\%; Nordeste 28\%; Sudeste 42,3\%; Sul 14,5\%; CentroOeste $7,2 \%$. 
saúde, eletricidade e saneamento. Essas são as áreas onde a reforma tem sentido e é necessária, pois desconcentra as terras e otimiza a sua utilização; é nessas regiões que a agricultura camponesa pode conseguir mais facilmente sucesso de forma autônoma, já que a intervenção do Estado é insignificante frente ao verificado em países desenvolvidos. Tendo isso em mente, as ocupações na metade meridional do país são as que mais contribuem para a realização da reforma agrária, pois é nessas regiões que a estrutura concentrada já estabelecida deve ser reformada.

MAPA 1

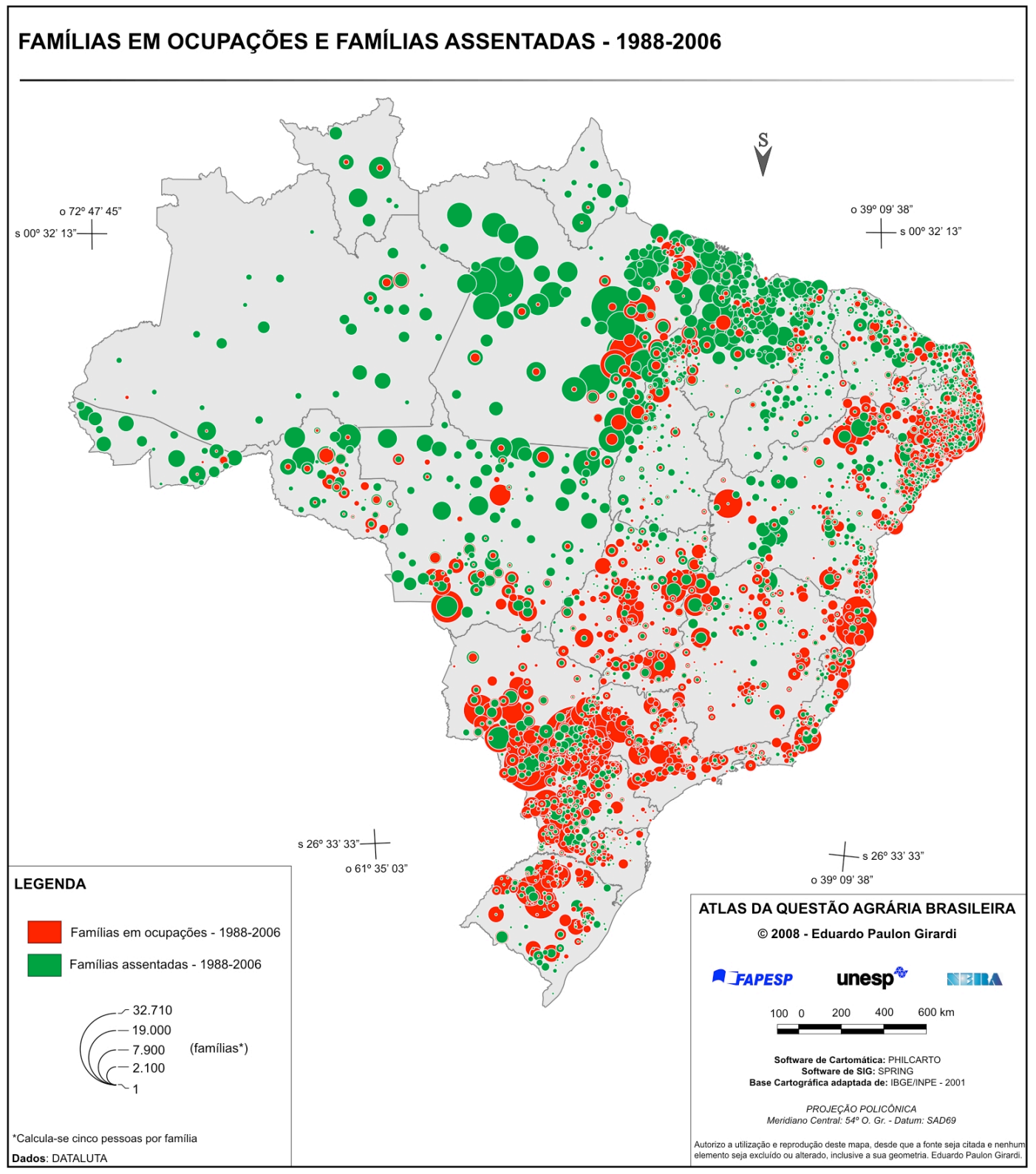

A partir deste primeiro indício da ineficácia regional da política de assentamentos, analisamos a potencialidade reformadora dos diversos tipos de assentamentos rurais. A origem da terra para a criação dos assentamentos é o principal elemento que consideramos na análise. Os assentamentos podem ser criados a partir de a) 
terras desapropriadas, cujos proprietários são indenizados (a terra é comprada pelo Estado); b) reconhecimento de posses e c) projetos de conservação ambiental, que reconhecem unidades de conservação de uso sustentável como assentamentos. Em todos os casos as famílias assentadas são consideradas beneficiárias da "reforma agrária" e têm acesso aos programas de crédito e recursos para instalação previstos no II PNRA. A tabela 3 mostra os 18 tipos de assentamentos do INCRA e os dados concernentes.

TABELA 3 - Brasil - Tipos de assentamentos rurais - 1979-2006

\begin{tabular}{|c|c|c|c|}
\hline Tipo de assentamento & $\begin{array}{c}\text { Número de } \\
\text { assentamentos }\end{array}$ & $\begin{array}{c}\text { Famílias } \\
\text { assentadas }\end{array}$ & Área (ha) \\
\hline CQ - Comunidades Quilombolas & 1 & 53 & 890 \\
\hline FLONA - Florestas nacionais & 14 & 3.735 & 4.463 .081 \\
\hline PA - Proj. de Assentamento Federal & 6.197 & 711.839 & 31.649 .960 \\
\hline PAC - Proj. de Assentamento Conjunto & 16 & 7.887 & 551.391 \\
\hline PAD - Proj. de Assentamento Dirigido & 8 & 7.275 & 458.694 \\
\hline PAE - Proj. de Assentamento Agroextrativista & 199 & 51.046 & 7.138 .699 \\
\hline PAF - Proj. de Assentamento Florestal & 3 & 275 & 67.353 \\
\hline PAM - Proj. de Assentamento Municipal & 2 & 140 & 8.360 \\
\hline PAR - Proj. de Assentamento Rápido & 3 & 1.214 & 274.843 \\
\hline PC - Proj. de Colonização Oficial & 6 & 885 & 8.532 \\
\hline PCA - Proj. de Assentamento Casulo & 93 & 4.443 & 20.242 \\
\hline PDS - Proj. de Desenvolvimento Sustentável & 84 & 24.765 & 2.945 .086 \\
\hline PE - Proj. de Assentamento Estadual & 815 & 61.149 & 2.669 .778 \\
\hline PFP - Proj. de Fundo de Pasto & 129 & 4.414 & 151.603 \\
\hline PIC - Proj. Integrado de Colonização & 2 & 757 & 18.346 \\
\hline PRB - Proj. de Reassentamento de Atingidos por Barragens & 55 & 1.897 & 96.095 \\
\hline RDS - Reserva de Desenvolvimento Sustentável & 6 & 2.000 & 5.673 .710 \\
\hline RESEX - Reserva Extrativista & 33 & 29.272 & 8.356 .104 \\
\hline TOTAL & 7.666 & 913.046 & 64.552 .767 \\
\hline $\begin{array}{l}\text { Dados: DATALUTA } \\
\text { Org.: Eduardo Paulon Girardi }\end{array}$ & & & \\
\hline
\end{tabular}

Além da origem da terra, os assentamentos possuem outras características que consideramos na análise, para as quais nos baseamos em Rocha (2008). Classificamos os assentamentos em não reformadores e reformadores. O grupo dos assentamentos não reformadores compreende os seguintes tipos (tabela 3), cujas características são: CQ e PFP: reconhecimento de terras e beneficiários ${ }^{14}$; FLONA, PAE, PAF, PDS, RDS, RESEX: caráter ambiental, reconhecimento de terras e beneficiários; PAC, PC e PIC: projetos de colonização de novas áreas; PDA: colonização e titulação; PAR: titulação de posses; PRB: beneficiários e compensação de passivo social. O grupo dos assentamentos reformadores compreende os tipos PA, PAM, PCA e PE, cujas terras de origem são, em grande, parte desapropriadas.

\footnotetext{
${ }^{14}$ Por beneficiários, designamos as formas de assentamentos em que o acesso à terra não foi possibilitado pelo Estado, que atuou principalmente com o reconhecimento do direito de uso ou de propriedade. Os beneficiários são contabilizados como assentados pelo fato de terem direito a recursos financeiros de estabelecimento na terra e créditos direcionados à agricultura familiar.
} 
De modo geral, os assentamentos não reformadores são os reconhecimentos de posse, assentamentos criados a partir de terras públicas, unidades de conservação sustentáveis e outros projetos de caráter ambiental. Esses assentamentos se confundem com as políticas ambiental e de ocupação do território. A criação de unidades de conservação de uso sustentável, reconhecidas como assentamentos rurais, não desconcentra a terra. Essas áreas não fazem parte da estrutura fundiária e geralmente são criadas em terras públicas, o que não implica em desapropriação de terras. A regularização de posses também não implica em desapropriação de terras. Desta forma, consideramos que o reconhecimento de posses e a criação de assentamentos em terras públicas são formas de alterar a estrutura fundiária com a adição de novas áreas e de novos detentores, sem que seja necessário reformar as áreas que previamente compunham a estrutura fundiária, ou seja, dividir as terras. No caso dos assentamentos não reformadores o campesinato se territorializa sem que haja a desterritorialização do latifúndio. Para os assentamentos reformadores ${ }^{15}$ as terras são arrecadadas geralmente a partir de desapropriação, o que representa o mais alto grau de reforma da estrutura fundiária possível na legislação brasileira atual. Através da criação desses tipos de assentamentos é cumprido o artigo 186 da Constituição e a estrutura fundiária é de fato desconcentrada: com os assentamentos reformadores o campesinato se territorializa a partir da desterritorialização do latifúndio e isso é reforma da estrutura fundiária.

Entre os assentamentos criados no período 1979-2006, os reformadores são $92,7 \%$ e comportam $85,1 \%$ das famílias em $53,2 \%$ da área total. A tabela 4 mostra que no primeiro mandato de FHC a ênfase foi na criação de assentamentos reformadores. Já no segundo mandato, paralelamente à diminuição pela metade do número total de assentamentos criados e de famílias assentadas, houve aumento da proporção dos assentamentos não reformadores, em especial dos de caráter ambiental. No primeiro mandato de Lula os dados dos assentamentos reformadores são muito próximos daqueles verificados no segundo mandato de FHC. A particularidade do primeiro mandato de Lula é a intensificação da criação de assentamentos não reformadores, em especial os de caráter ambiental. Esses assentamentos não reformadores correspondem, no primeiro mandato de Lula, a $21 \%$ dos assentamentos criados, $43 \%$ das famílias assentadas e $80 \%$ da área total e, portanto, uma política agrária mais conservadora.

\footnotetext{
${ }^{15}$ Alguns tipos de assentamentos reformadores também podem ser criados a partir de terras públicas, o que ocorre principalmente na fronteira agropecuária. Por não termos informações detalhadas a este respeito, não iremos particularizar esses assentamentos dentro do grupo reformadores. Caso houvesse possibilidade de particularizarmos, a conseqüência seria diminuir ainda mais o número de assentamentos reformadores, já que consideramos não reformadores os assentamentos criados a partir de terras públicas.
} 
TABELA 4 - Brasil - Assentamentos não reformadores e assentamentos reformadores por períodos de governo

\begin{tabular}{|c|c|c|c|c|c|c|c|c|c|c|c|c|}
\hline \multirow[t]{2}{*}{ Grupo } & \multicolumn{3}{|c|}{$1979-1994$} & \multicolumn{3}{|c|}{$\begin{array}{c}\text { Primeiro mandato FHC } \\
(1995-1998)\end{array}$} & \multicolumn{3}{|c|}{$\begin{array}{c}\text { Segundo mandato FHC } \\
(1999-2002)\end{array}$} & \multicolumn{3}{|c|}{$\begin{array}{c}\text { Pimeiro mandato Lula } \\
(2003-2006)\end{array}$} \\
\hline & Assent. & Fam. & Area & Assent. & Fam. & Area & Assent. & Fam. & Area & Assent. & Fam. & Area \\
\hline Não reformadores & 41 & 19.465 & 3.082 .210 & 6 & 1.225 & 1.390 .212 & 27 & 4.018 & \begin{tabular}{|l|}
2.241 .986 \\
\end{tabular} & 485 & 110.767 & \begin{tabular}{|l|}
23.490 .019 \\
\end{tabular} \\
\hline de caráter ambiental & 23 & 7.502 & 2.124 .027 & 4 & 1.083 & 1.388 .732 & 14 & 2.765 & 2.232 .999 & 298 & 99.743 & 22.898 .275 \\
\hline outros & 18 & 11.963 & 958.183 & 2 & 142 & \begin{tabular}{|r|}
1.480 \\
\end{tabular} & 13 & 1.253 & \begin{tabular}{|r|}
8.987 \\
\end{tabular} & 187 & 11.024 & 591.744 \\
\hline Reformadores & 1.034 & 183.894 & 9.810 .428 & 2.375 & 299.138 & \begin{tabular}{|l|}
12.164 .872 \\
\end{tabular} & 1.890 & 153.287 & 6.573.489 & 1.808 & 141.252 & 5.799 .551 \\
\hline Total Brasil & 1.075 & 203.359 & 12.892 .638 & 2.381 & \begin{tabular}{|l|}
300.363 \\
\end{tabular} & \begin{tabular}{|l|}
13.555 .084 \\
\end{tabular} & 1.917 & 157.305 & \begin{tabular}{|l|}
8.815 .475 \\
\end{tabular} & 2.293 & 252.019 & \begin{tabular}{|l|}
29.289 .570 \\
\end{tabular} \\
\hline
\end{tabular}

Se considerarmos somente os assentamentos reformadores entre 1988 e 2006, contabilizamos $6.704\left(92,7 \%{ }^{16}\right)$ assentamentos com $29.625 .441(51,7 \%)$ ha, nos quais foram assentadas $689.345(85,4 \%)$ famílias. Não sabemos quais desses assentamentos foram criados por iniciativa do governo ou pela demanda local dos movimentos socioterritoriais camponeses, entretanto, as ocupações de terra podem fornecer pistas. Partindo deste princípio, podemos dividir os assentamentos reformadores em a) criados em municípios nos quais houve ocupação de terra e b) criados em municípios nos quais nunca houve ocupação de terra ${ }^{17}$. Segundo esta divisão, os assentamentos reformadores criados em municípios com ocupação de terra entre 1988 e 2006 são 4.425 (61,2\% $\left.{ }^{18}\right)$, com 412.140 $(51,1)$ famílias assentadas e $15.322 .995(26,7 \%)$ hectares.

O mapa 2 representa as famílias assentadas entre 1988 e 2006 segundo os três tipos de assentamentos sobre os quais escrevemos até então: a) assentamentos reformadores de municípios com ocupações de terra; b) assentamentos reformadores de municípios sem ocupações de terra e c) assentamentos não reformadores. O diferencial territorial do mapa mostra que há uma ordem regional da classificação que propomos. Os assentamentos reformadores criados em municípios onde ocorreram ocupações de terra (verde escuro) são predominantes nas regiões de ocupação consolidada. Os assentamentos reformadores criados em municípios sem ocorrência de ocupações de terra (verde claro)

\footnotetext{
${ }^{16}$ Em relação ao total dos 18 tipos de assentamento (ver tabela 2).

${ }^{17}$ Os assentamentos rurais, mesmo que fruto das demandas dos movimentos socioterritoriais camponeses através das ocupações de terra, não são criados no mesmo ano em que ocorre o ato de ocupação. Também não há um banco de dados que disponibilize informações sobre a história de criação de todos os assentamentos. Por isso, não consideramos em nossa classificação a relação direta entre ocupação de uma determinada área e criação de assentamento nesta mesma área. Por isso, foi necessário generalizar a classificação, de modo que, mesmo que um assentamento reformador tenha sido criado em 1988 e a primeira ocupação de terra no município tenha ocorrido só em 2006, este assentamento e todos os demais no município, independente do ano de criação, foram classificados como "assentamento reformador de município com ocorrência de ocupação". Isso indica que os dados sobre os assentamentos reformadores de municípios com ocupação de terra são, no mínimo, sobrevalorizados, de forma que o conservadorismo da reforma agrária, com a criação espontânea de assentamentos pelos governos em regiões inadequadas/desnecessárias à reforma agrária é ainda maior.

${ }^{18}$ Em relação ao total dos 18 tipos de assentamento (ver tabela 2).
} 
configuram uma faixa de transição arqueada que vai do oeste do Mato Grosso até o Maranhão, nas bordas da Amazônia. O terceiro grupo, dos assentamentos não reformadores (amarelo), concentra-se principalmente na metade noroeste da Amazônia Legal. O mapeamento confirma a hierarquia do grau de reforma dos assentamentos, já que os assentamentos reformadores em municípios sem ocorrência de ocupação de terra estão localizados principalmente em regiões de ocupação recente, que configuraram a fronteira agropecuária nas décadas de 1980 e 1990. O mapa 2 evidencia o conservadorismo da reforma agrária.

\section{MAPA 2}

\section{FAMÍLIAS ASSENTADAS E TIPOS DE ASSENTAMENTO - 1988-2006}

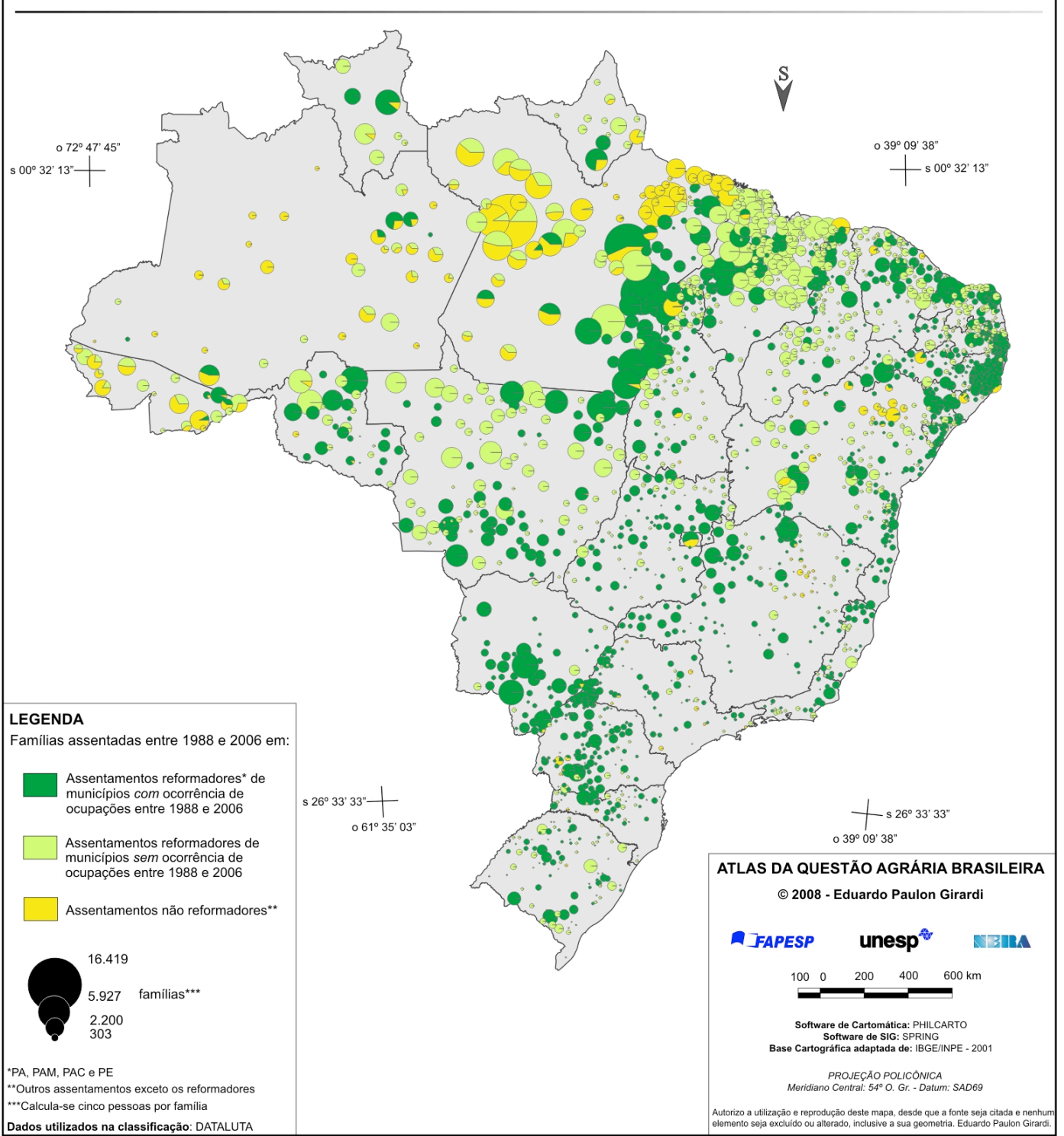


Partindo do princípio de que as ações dos movimentos socioterritoriais são a medida de indicação dos problemas fundiários das localidades (municípios) e o assentamento das famílias nessas mesmas localidades indica a tentativa de solução dos problemas pelo Estado, propomos o indice de assentamento. A elaboração do índice consiste em a) selecionar os municípios em que tenha havido ocupação de terra no período considerado; b) subtrair o número de famílias em ocupações (FO) do número de famílias assentadas em assentamentos reformadores (FAR); c) dividir 100 pelo maior valor verificado entre os municípios na operação FO - FAR; d) multiplicar o resultado da etapa $c$ pelo caso FO - FAR verificado em cada município e e) dividir o resultado por 100. Desta forma, temos um índice sintético que varia de -1 a 1 . Os valores positivos, com máximo em 1, indicam o atendimento às demandas locais por terra; já os valores negativos, com mínimo em -1, indicam que a demanda não é atendida e que a luta pela terra é mais intensa e mais longa. Este índice é capaz de indicar a solução ou não dos problemas fundiários locais pela política de assentamentos rurais, já que o local é tomado como referência e os dados das políticas não são diluídos em escala nacional.

O mapa 3 representa o índice de assentamento. Os valores positivos estão principalmente na metade noroeste do país e os índices negativos se concentram na metade sudeste. No mapa 4 vemos que os municípios com maiores índices são os que concentram a maior parte das famílias assentadas, o que já era previsto. É nesses municípios amazônicos que os governos têm concentrado a criação de assentamentos para da uma resposta quantitaiva à sociedade. Os baixos índices nas regiões onde predominam as ocupações de terra (centro-sul e Nordeste) confiram a ineficácia local no atendimento das demandas dos movimentos socioterritoriais, o que é mais uma confirmação da reforma agrária conservadora da qual tratamos neste artigo. 
MAPA 3

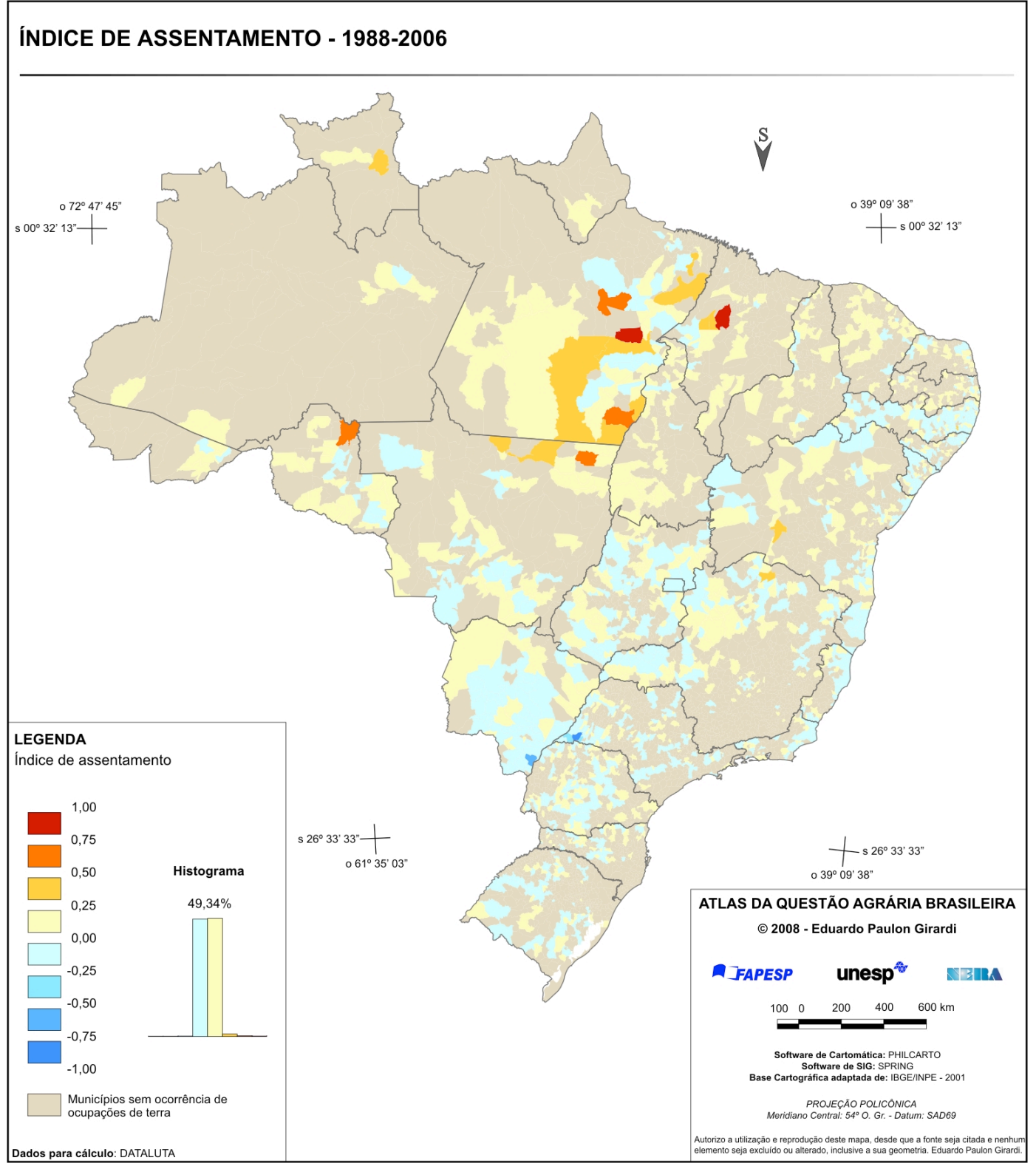




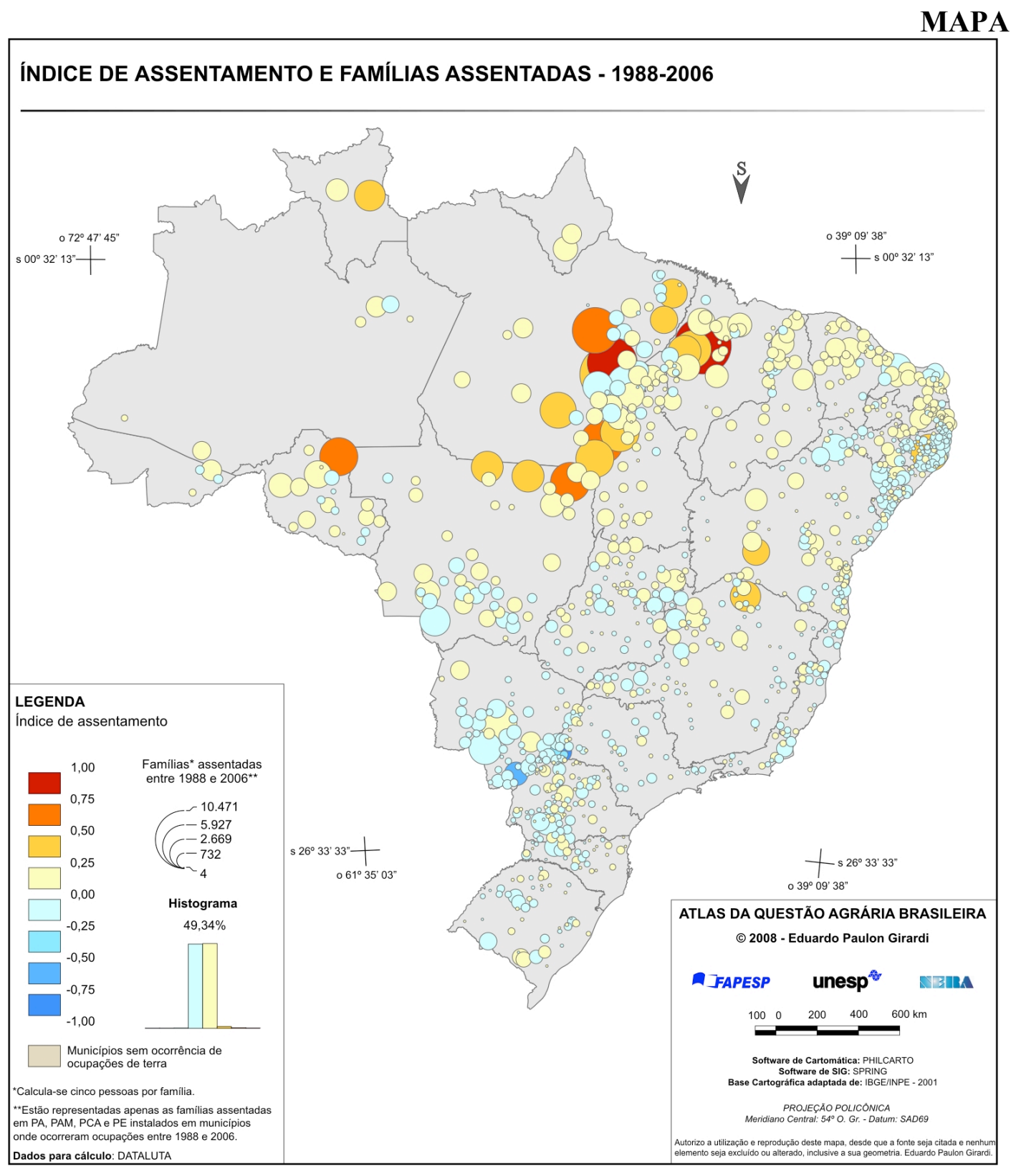

Os mapas 5 e 6 evidenciam a importância dos assentamentos não reformadores na Amazônia. No mapa 2 está representada a área total dos imóveis rurais em 2003 e a área dos assentamentos rurais (todos os 18 tipos da tabela 3) criados desde 1988. O mapa mostra que na Amazônia oriental a área dos assentamentos é maior do que a área total dos imóveis rurais. Isso ocorre por que a maior parte dos assentamentos de caráter ambiental não conta na estrutura fundiária por ser referente às unidades de conservação. A confirmação está na comparação dos mapas 2 e 3, já que no mapa 3 é representada apenas a área dos assentamentos reformadores e, por isso, a área dos assentamentos não ultrapassa a área total dos imóveis, a não ser por uma exceção no 
Mato Grosso e outra no Pará. Esses dois mapas, juntamente com o mapa 4, ajudam a sustentar a afirmação de que a reforma agrária conservadora tem se sustentado principalmente na Amazônia com a assimilação de projetos ambientais e de ocupação da região.

Um tema polêmico e bastante recorrente nos discursos contra reforma agrária é a participação dos assentamentos rurais no processo de ocupação e desflorestamento da Amazônia, o que os mapas 5 e 6 também ajudam a desmistificar. Os mapas mostram que, apesar dos assentamentos fazerem parte da política de ocupação da região, a sua área em relação à área total apropriada é pequena, de forma que a maior parte da Amazônia é ocupada por atividades agropecuárias tradicionais a partir da apropriação das terras por particulares. O mapa 6 mostra a real participação dos assentamentos na ocupação da Amazônia, pois representa apenas os assentamentos reformadores em relação à área total dos imóveis dos municípios. Tomamos apenas os assentamentos reformadores por que esses são os que apresentam impacto mais importante, visto que grande parte dos demais são unidades de conservação sustentáveis, sendo assim seu impacto reduzido. Isso indica que, embora a Amazônia seja o principal escape para o desenvolvimento da política de assentamentos rurais, não podemos associar o processo ocupação da região exclusivamente ou majoritariamente aos assentamentos. A maior parte da ocupação é promovida pela ocupação particular e não pelos assentamentos. 
A luta pela terra e a política de assentamentos rurais no Brasil: a Reforma Agrária 93 conservadora, pp. 73-98.

MAPA 5

IMÓVEIS RURAIS E ASSENTAMENTOS RURAIS

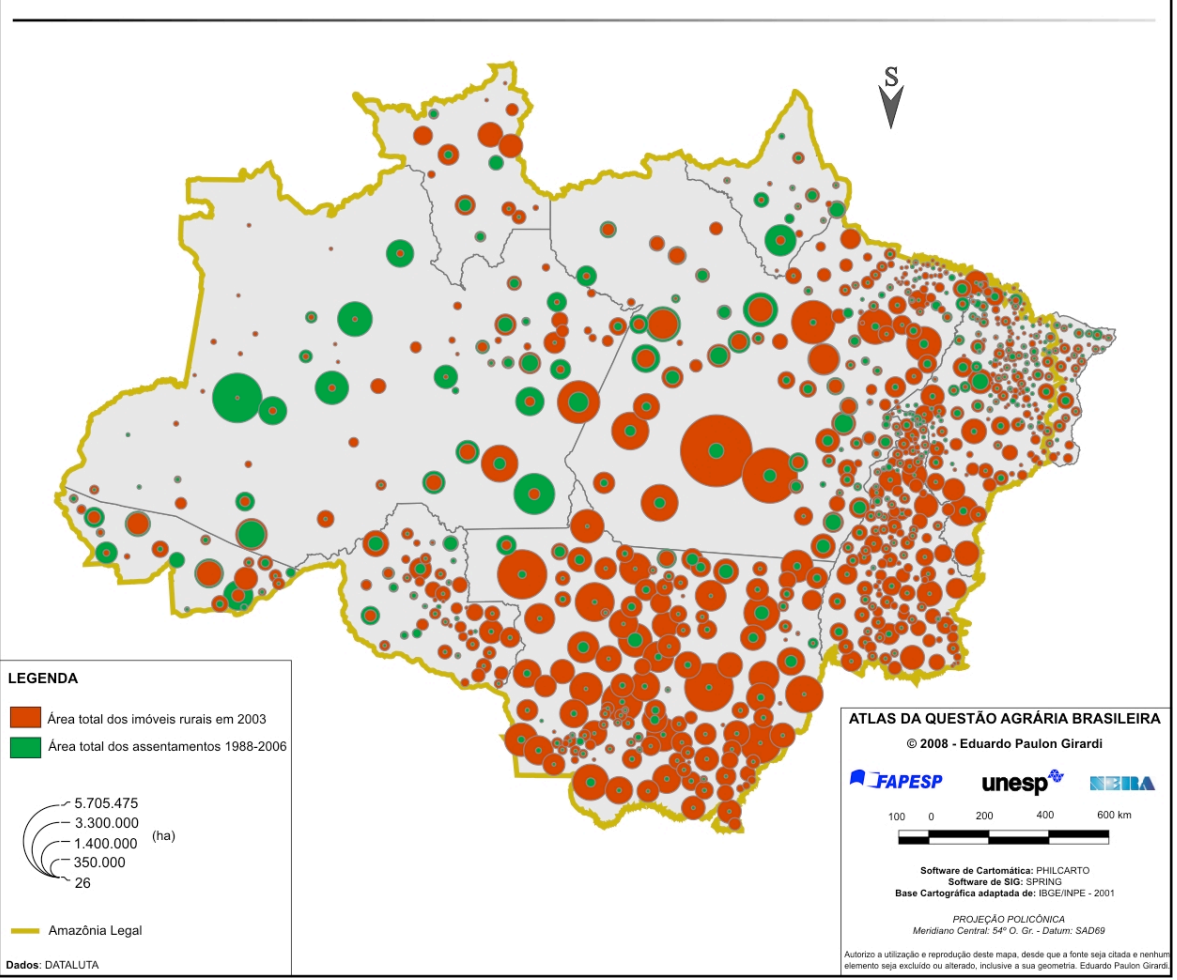

MAPA 6

IMÓVEIS RURAIS E ASSENTAMENTOS REFORMADORES *

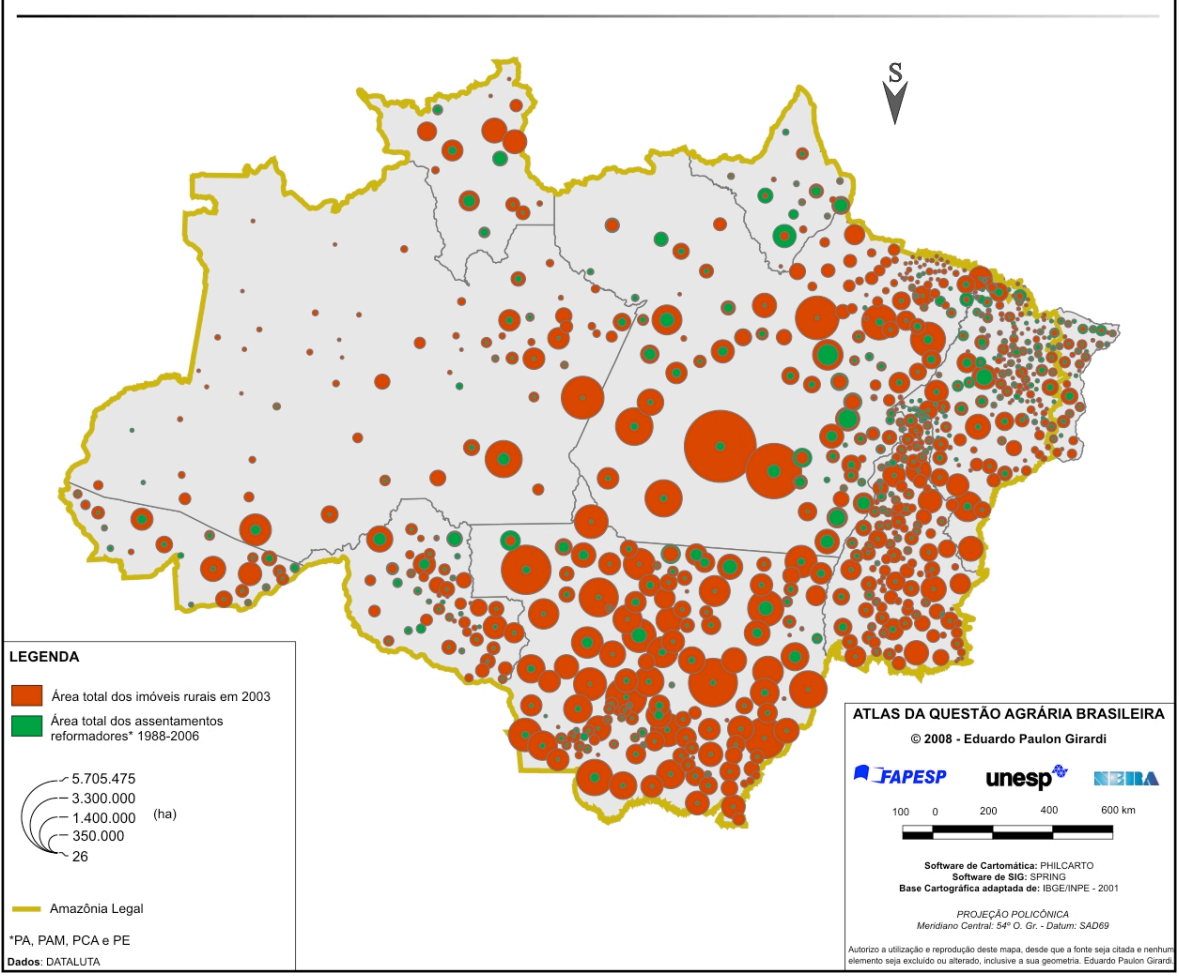

MAPA 7 


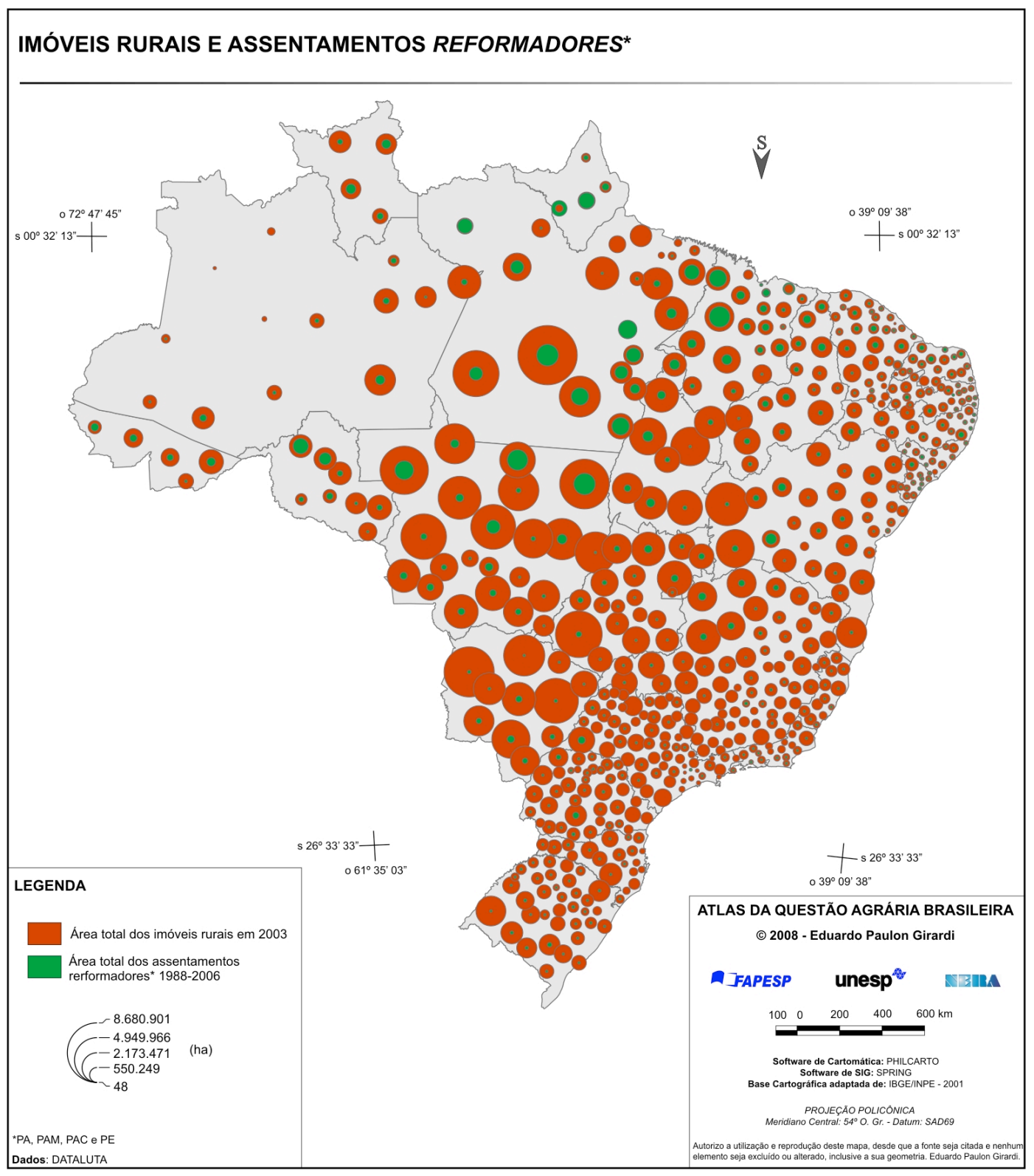

\section{CONSIDERAÇÕES FINAIS}

Em 1998 as terras exploráveis não exploradas no Brasil totalizavam 75,4 milhões de hectares, dos quais $45 \%$ estavam na região Norte. Desta forma, para fins de reforma agrária, se desconsiderássemos as terras exploráveis não exploradas da região Norte, teríamos ainda 41 milhões de hectares reformáveis (10 milhões de ha a mais do que toda a área de assentamentos reformadores criados entre 1988 e 2006). É necessário lembrar que esta estimativa foi declarada pelos detentores dos imóveis, podendo assim a superfície real reformável ser superior. Além disso, é necessário verificar as terras que não cumprem a função social a partir de outros elementos como 
crimes ambientais e trabalhistas, o que aumentaria ainda mais a área reformável. O Censo Agropecuário 2006 do IBGE poderia indicar esta superfície, porém na pesquisa, o instituto não contabilizou separadamente as áreas exploráveis não utilizadas. Esta foi uma opção negativa do instituto na contribuição para a análise da estrutura agrária do país. Em resumo, 40 milhões de hectares é sem dúvida um valor aquém do que é realmente reformável no Brasil (exceto a região Norte), de forma que não faltam terras para a reforma agrária, mas sim vontade política para realizá-la.

Para não alterar a estrutura fundiária das regiões de ocupação consolidada e desenvolver a política de assentamentos com ainda menos recursos, a região da fronteira agropecuária da Amazônia, principalmente a frente pioneira, tem sido utilizada para assentar as famílias em assentamentos não reformadores. Um dos argumentos para não reformar outras regiões do país é o preço das terras. A aquisição de terras pode ser menos onerosa na região de fronteira, entretanto, se o assentamento das famílias nessas regiões fosse realizado de forma adequada para garantir boa qualidade de vida e produção às famílias, provavelmente exigiria ainda mais recursos do que os necessários para obter terras em outras regiões do país. Isso por que, como sabemos, a frente pioneira é caracterizada pela baixa densidade de infra-estrutura, precariedade de serviços básicos e mercado consumidor rarefeito. Nesta região os assentamentos são precariamente instalados, o que faz com que a estratégia de gastar menos com a reforma agrária na fronteira agropecuária funcione, já que o interesse é o número de famílias assentadas e não a qualidade de vida dessas famílias. A expropriação da terra ao invés da desapropriação poderia ser uma alternativa para possibilitar uma reforma mais ampla, porém isso não é previsto na lei. Assim, a não reforma de áreas de ocupação consolidada é uma decisão política para conservar a elite agrária, principalmente no centro-sul e Nordeste, e reservar as terras para a territorialização do agronegócio. Isso possibilita a esta elite ainda mais riqueza e poder, a exemplo do que vem ocorrendo em São Paulo com a cana-de-açúcar. Esta opção política é sem dúvida a principal causa da reforma agrária conservadora.

Outro caráter conservador da política agrária brasileira, que consiste basicamente na política de assentamentos rurais, é que ela não consegue sequer zerar o saldo migratório campo-cidade e manter os postos de trabalho no campo. Como mostramos na introdução, entre 1991 e 2000 migraram para a cidade 4,2 milhões de brasileiros e entre 1996 e 2006 1,5 milhões de postos de trabalho foram eliminados no 
campo. No período 1991-2000 foram assentadas 444 mil famílias, cerca de 2,2 milhões de pessoas, o que ainda mostra um que o êxodo rural ainda é negativo em dois milhões de pessoas. Quanto aos postos de trabalho, se considerarmos duas pessoas ocupadas por cada uma das 646 mil famílias assentadas no período, temos a "criação" de 1,3 milhões de postos de trabalho no campo - um saldo negativo de 200 mil postos de trabalho no campo. Contudo, é necessário que seja feita uma ressalva nesses cálculos com base nas análises sobre assentamentos reformadores e não reformadores: parte significativa dessa população "levada para o campo com os assentamentos" já residia no campo e parte desses postos de serviço "criados" com os assentamentos já existiam, o que ocorreu foi a inserção dessas população na política agrária através da legalização de posses e do reconhecimento de unidades de conservação de uso sustentável como assentamentos rurais. Daí conclui-se que a política de assentamentos rurais, além de pecar pela qualidade, sobre a qual não falamos neste artigo mas que é mostrada por vários trabalhos, não consegue sequer reverter o êxodo rural que continua no país sem nenhum sentido que possa contribuir para o desenvolvimento social.

O caráter mais conservador da reforma agrária brasileira é o programa de crédito chamado de reforma agrária de mercado, iniciado no governo FHC com o Banco da Terra e hoje transformado no programa Cédula da Terra. Este programa, que segue as indicações do Banco Mundial para a "reforma agrária", tem como principal instrumento a concessão de crédito para a compra de pequenas propriedades. Desta forma, o Estado se torna ainda mais distante das ações, que neste caso são ditadas pelo mercado de terras. Destacamos que não trabalhamos com os dados deste programa de crédito nas análises realizadas neste artigo.

O problema da reforma agrária conservadora está na não reforma das regiões de ocupação consolidada (centro-sul e Nordeste). A intervenção no ordenamento da fronteira agropecuária com a criação de assentamentos, reconhecimento de pequenas posses e criação de áreas de manejo sustentável exploradas por camponeses é sem dúvidas positivo: essas políticas permitem a territorialização do campesinato, garantem acesso aos recursos de crédito e fazem com que os camponeses "invisíveis" até então sejam reconhecidos e melhorem sua condição de vida. As unidades de manejo sustentável reconhecidas como assentamentos constituem um passo importante no reconhecimento dos direitos dos povos da floresta, especialmente representativos no Norte do país. O fato é que a criação de assentamentos não reformadores não pode suplantar a reforma nas regiões de ocupação consolidada. O problema não está na 
criação dos assentamentos não reformadores, mas sim como eles são utilizados como estratégia para não reformar as outras regiões do país. Como mostram os dados, não houve progresso na criação de assentamentos reformadores entre 1999 e 2006, pelo contrário, houve o crescimento da criação de assentamentos não reformadores, o que contribuiu para a conservação de valores muito elevados no índice de Gini da estrutura fundiária.

As ações na fronteira agropecuária certamente fazem parte da reforma agrária, porém não bastam; elas devem ser conduzidas paralelamente à reforma das demais regiões, que deve ser mais importante. Devido às particularidades da região da fronteira agropecuária amazônica, os projetos de caráter ambiental devem ser particularmente seguidos de perto pelo Estado para que a sustentabilidade não seja colocada em cheque pela miséria, contra a qual não há argumentos. A instituição de programas de renda mínima aos assentados - e aos camponeses de forma geral - é indispensável e tem tripla significação: a) contribui para resolução do problema agrário; b) contempla a problemática ambiental e c) é uma oportunidade ímpar para deter o intenso êxodo rural ainda em marcha no país.

\section{REFERÊNCIAS BIBLIOGRÁFICAS}

BRASIL - GOVERNO FEDERAL. Ministério do Desenvolvimento Agrário. II Plano Nacional de Reforma Agrária: paz, produção e qualidade de vida no meio rural. Brasília: Ministério do Desenvolvimento Agrário, 2003.

CONSTITUIÇÃO DA REPÚBLICA FEDERATIVA DO BRASIL DE 1988. 20.ed. Brasília: Câmara dos Deputados, 2003.

FAO - ORGANIZAÇÃO DAS NAÇÕES UNIDAS PARA A ALIMENTAÇÃO E A AGRICULTURA. Monitoring progress towards hunger reduction targets of the Wold Food Submmit (WFS) and the Millennium Development Goals (MDG). FAO: Roma, 2008. Disponível em: $<$ www.fao.org $>$.

GIRARDI, Eduardo Paulon. Proposição teórico-metodológica de uma Cartografia Geográfica Crítica e sua aplicação no desenvolvimento do Atlas da Questão Agrária Brasileira. 2008. Tese (Doutorado em Geografia) - Faculdade de Ciências e Tecnologia, Universidade Estadual Paulista, Presidente Prudente, 2008. Disponível em: $<$ www.fct.unesp.br/nera/atlas $>$.

GÓMEZ, J. R. M. Desenvolvimento em (des)construção: narrativas escalares sobre desenvolvimento territorial rural. Presidente Prudente, 2006. Tese (Doutorado em Geografia) - Faculdade de Ciências e Tecnologia, Universidade Estadual Paulista, 2006 . 
IBGE - INSTITUTO BRASILEIRO DE GEOGRAFIA E ESTATÍSTICA. Censo agropecuário 2006. Rio de Janeiro: IBGE, 2006a. Disponível em: <www.ibge.gov.br>.

PNAD - Pesquisa Nacional por Amostra de Domicílios 2007. IBGE: Rio de Janeiro, 2007. Disponível em: <www.ibge.gov.br $>$.

Segurança alimentar 2004. IBGE: Rio de Janeiro, 2006. Disponível em: $<$ www.ibge.gov.br $>$.

NERA - NÚCLEO DE ESTUDOS, PESQUISAS E PROJETOS DE REFORMA AGRÁRIA. DATALUTA - Banco de dados da luta pela terra. Presidente Prudente:

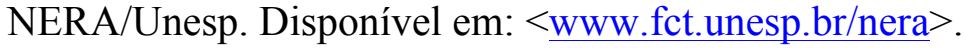

PINTO JR., J. M.; FARIAS, V. A. Função social da propriedade: dimensões ambiental e trabalhista. Brasília: Núcleo de Estudos Agrários e Desenvolvimento Rural, 2005 .

ROCHA, H. F. Análise e mapeamento dos tipos de assentamentos no Brasil. Presidente Prudente, 2008. Relatório (Iniciação Científica em Geografia) - Faculdade de Ciências e Tecnologia, Universidade Estadual Paulista, 2008. 